\title{
Methods for On-Orbit Germination of Arabidopsis thaliana for Proteomic Analysis
}

\author{
Sarahann Hutchinson ${ }^{1}$, Proma Basu ${ }^{2}$, Sarah E. Wyatt ${ }^{2}$, and Darron R. Luesse ${ }^{1}$ \\ ${ }^{I}$ Department of Biological Sciences, Southern Illinois University Edwardsville, Edwardsville, IL; ${ }^{2}$ Department of \\ Environmental and Plant Biology, Ohio University, Athens, $\mathrm{OH}$
}

\begin{abstract}
Large-scale omics approaches make excellent choices for research aboard the International Space Station (ISS) because they provide large amounts of data that can be continually mined even after the original research has been completed. A proteomic approach can provide information about which proteins are produced, degraded, or post-translationally modified, potentially shedding light on cellular strategies that cannot be discerned from transcriptomic data. To collect sufficient tissue from a Biological Research In Canisters (BRIC)-grown experiment on the ISS for proteomic analysis, several modifications were made to existing protocols. Approximately 800-1000 seeds were housed in each Petri Dish Fixation Units (PDFU). These were germinated up to $120 \mathrm{~h}$ after planting by transferring the BRIC from cold stasis to room temperature. Growth continued for only $72 \mathrm{~h}$ after germination to allow sufficient tissue for
\end{abstract}

Key words: $\quad$ Arabidopsis; Proteomics; Transcriptomics; BRIC; ISS; RNAlater ${ }^{\circledR}$

Correspondence to: Darron R. Luesse

Southern Illinois University Edwardsville

Box 1651

44 Circle Dr.

Edwardsville, IL 62026

Telephone: 618-650-2153

E-mail: dluesse@siue.edu extraction, and to minimize the impact of ethylene and crowding stress. Seedlings were then exposed to RNAlater ${ }^{\circledR}$. Results indicate that RNAlater ${ }^{\circledR}$ treated Arabidopsis seedlings yield an equal amount of protein to those flash-frozen in liquid nitrogen.

\section{INTRODUCTION}

The use of proteomics to track relative protein expression is becoming a common approach to understand how an organism responds on a molecular level to a variety of environmental conditions or genetic mutations. Historically, a transcriptomic approach has been used to understand changes in plant gene expression during spaceflight (Beaulieu et al., 2013; Paul et al., 2005; Paul et al., 2012; Paul et al., 2013; Salmi and Roux 2008; Salmi et al., 2011a; Salmi et al., 2011b). This is an attractive approach because vast quantities of data can be obtained from very little tissue. However, changes in gene expression do not necessarily reflect direct changes in protein quantity (Griffin et al., 2002). Considering that the presence of active protein is the final determinant of a cellular response to a given environmental stimulus, a proteomic approach can provide more reliable data. In addition to protein production, proteomics can also identify protein degradation, as well as post translational modifications, such as phosphorylation, which can be critical for activating or inactivating function. 
One of the main drawbacks to using proteomics as a tool to analyze the microgravity environment is the amount of tissue required to obtain sufficient material for analysis. Experiments that use the popular and accessible Biological Research In Canisters (BRIC) hardware are typically limited to a handful of seedlings growing on a few $60 \mathrm{~mm}$ Petri dishes, often in the dark (Kuznetsov et al., 2001; Millar et al., 2011). Under these conditions, lifespan is short, plants are limited to carbon sources from the media when producing biomass, and stress from etiolated growth can confound analysis of the stress induced by microgravity by alternatively regulating, and therefore masking, those genes that would normally appear in a microgravity transcriptomic data set

Improved isobaric tags and mass spectrometry technology have begun to make proteomics more accessible for research with limited tissue availability (Reviewed by Vanderschuren et al., 2013). To date, discovery proteomics has been used to analyze a variety of bacteria, mammalian cells, Saccharomyces cerevisiae, rice leaf tissue, Arabidopsis callus, and de-etiolated 12-d-old Arabidopsis seedlings (Ma et al., 2007; Crabbe et al., 2011; Grimm et al., 2011; Ferl et al., 2015). Previous plant samples have utilized lighted environments that allowed photosynthesis, carbon fixation, and increased plant mass. Here we focus on refining methods for performing proteomic analysis on Arabidopsis samples grown in the BRIC hardware, a dark environment with limited growth space. Specifically, planting density to obtain sufficient tissue, coordinated on-orbit germination in darkness, growth time, and preservation of sample protein content must all be refined to collect a useable sample for analysis (Figure 1). By utilizing high-density planting, a $72 \mathrm{~h}$ etiolated growth plan, and RNAlater ${ }^{\circledR}$ for protein stability, the BRIC hardware can be successfully used to generate proteomic data from etiolated Arabidopsis plants germinated and grown on-orbit aboard the ISS.

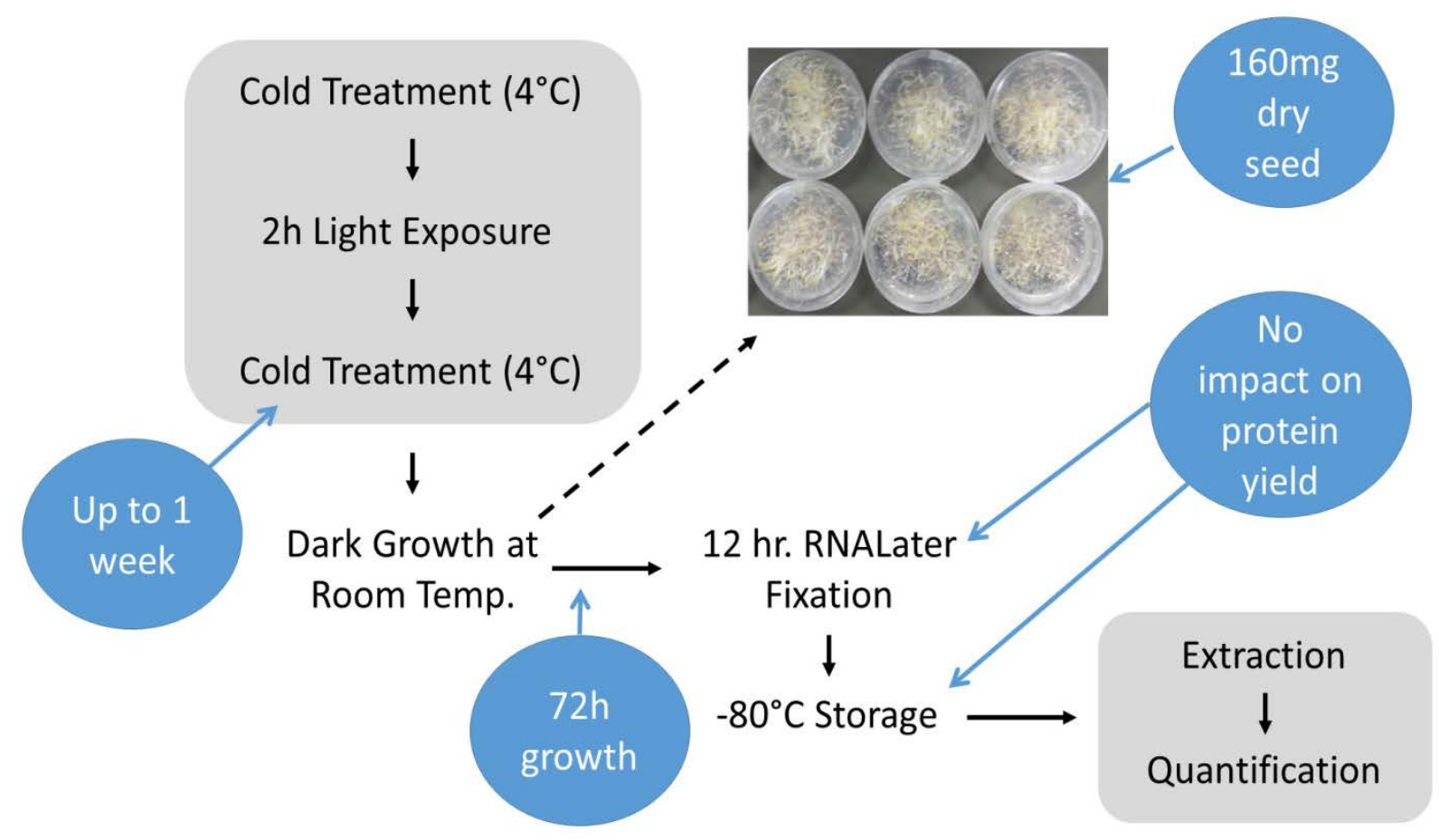

Figure 1. Protocol flow chart for proteomic analysis of BRIC-grown material. Blue ovals indicate aspects of the approach that are addressed in this work. 


\section{MATERIALS AND METHODS}

\section{Plant Growth}

Arabidopsis seeds in the Col-0 background were surface sterilized in $30 \%$ bleach $/ 0.01 \%$ Tween 20 solution. Sterile seeds were placed on individual filter paper discs to dry, prior to random planting across a $60 \mathrm{~mm}$ Petri dish containing $0.8 \%$ agar, 0.5x Murashige \& Skoog media (Caisson Laboratories, Smithfield, UT), and $1 \%$ sucrose. Unless otherwise indicated, Petri dishes were sealed with parafilm, wrapped in foil, and stratified for $48 \mathrm{~h}$ to $72 \mathrm{~h}$ prior to receiving 2 $\mathrm{h}$ white light to induce germination. Plants were then wrapped in foil and placed inside a modified coffee mug to approximate the BRIC environment.

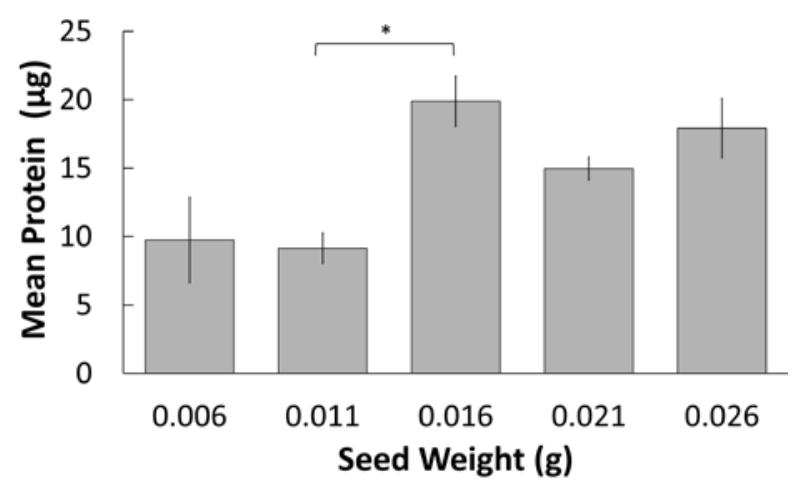

Figure 2. Comparison of mean protein yield by starting seed weight. Seed sets weighing between $0.026 \mathrm{~g}$ ( $\sim 1300$ seeds) to $0.006 \mathrm{~g}$ ( 300 seeds) were grown on plates for $96 \mathrm{~h}$ prior to protein extraction. * indicates $\mathbf{p}<\mathbf{0 . 0 3}$ using a Student's T-test. Bars represent an average of three separate extractions, each using approximately 1300 seeds. Error bars represent SEM.

\section{Cold Treatment to Delay Germination}

Modifications to the standard germination and growth timeline were made to accommodate the requirements of a flight schedule. After seeds were sown, plates were placed at $4^{\circ} \mathrm{C}$ in the dark for $18 \mathrm{~h}$, followed by a $2 \mathrm{~h}$ light treatment at room temperature. After light treatment, plates were returned to the cold. A subset of individually wrapped plates was removed every $48 \mathrm{~h}$ to score germination, preventing light contamination of the remaining plates. This germination and growth protocol was used to analyze cold storage prior to germination, as well as optimal growth time after transfer to room temperature.

\section{RNAlater ${ }^{\circledR}$ Treatment}

After growth for $96 \mathrm{~h}$ at room temperature, Petri dishes were flooded with $10 \mathrm{~mL}$ RNAlater ${ }^{\circledR}$ and resealed for $12 \mathrm{~h}$. Petri dishes with RNAlater ${ }^{\circledR}$ were then placed into the $-80^{\circ} \mathrm{C}$ freezer for $12 \mathrm{~h}$ to $72 \mathrm{~h}$, prior to protein isolation. Total soluble protein was extracted from whole seedlings as described previously (Basu et al., 2015). Protein yield was quantified using the Bradford Assay (Fisher Scientific). Absorption at $595 \mathrm{~nm}$ was compared to a bovine serum albumin (BSA) standard curve.

\section{RESULTS}

\section{High-Density Seed Plating to Improve Protein Yield}

Unlike transcriptomic approaches, proteomics requires a minimum of $50 \mathrm{~g}$ of protein per replicate (Murad et al., 2011). One option for obtaining this material, while limiting the number of Petri Dish Fixation Units (PDFUs) necessary, is the use of high-density planting. To determine the optimal number of seeds per plate, between 0.006 $\mathrm{g}$ and $0.026 \mathrm{~g}$ of Arabidopsis seed was sown on a $60 \mathrm{~mm}$ Petri dish and grown for $96 \mathrm{~h}$ in darkness. Protein extracts from one plate with $0.006 \mathrm{~g}$ of seed yielded approximately $7 \mathrm{~g}$ (Figure 2). Additional seed, up to $0.016 \mathrm{~g}$, improved yield, up to approximately 15-20 g protein. As seedlings from 3 plates were combined to form one replicate, $15-20 \mathrm{~g}$ protein per plate would be sufficient for the amount of protein required for one replicate. However, increasing the number of seeds above $0.016 \mathrm{~g}$ did not further improve results. Therefore, we determined that under these growth conditions $0.016 \mathrm{~g}$ was the optimal amount for planting.

\section{Cold Storage Can Delay Germination}

Research utilizing the ISS often requires a several-day stasis between integration of the biological sample into the flight hardware and experiment activation. It is critical that seedlings germinate in near-unison to prevent life-stage fluctuations in the data. However, seedlings must also not germinate early, exposing them to the 
accelerated gravity of launch and potential problems created by growth while in cold stowage. To mitigate this problem, seeds were sown on Petri dishes and allowed to imbibe at $4^{\circ} \mathrm{C}$ for approximately $18 \mathrm{~h}$, exposed to white light for $2 \mathrm{~h}$, and then returned to darkness at $4^{\circ} \mathrm{C}$ to determine how long germination could be delayed. Plants left at $4^{\circ} \mathrm{C}$ after the light treatment did not show visible indications of germination up to $168 \mathrm{~h}(7 \mathrm{~d})$, when a small percentage did begin to germinate. However, plants placed at $23^{\circ} \mathrm{C}$ immediately after light treatment began to show germination after $72 \mathrm{~h}$, with full germination apparent after 120 h (Figure 3). After 144 h (6 d) in the cold, return to room temperature led to visible germination of $95 \%$ of seeds after $44 \mathrm{~h}$ (Figure 4), indicating that this is an effective method to temporarily inhibit, yet uniformly induce germination.
No Light $\left(22^{\circ} \mathrm{C}\right)$

No Light $\left(4^{\circ} \mathrm{C}\right)$

\section{$1 \mathrm{~h}$ Light $\left(22^{\circ} \mathrm{C}\right)$}

$2 \mathrm{~h}$ Light $\left(4^{\circ} \mathrm{C}\right)$
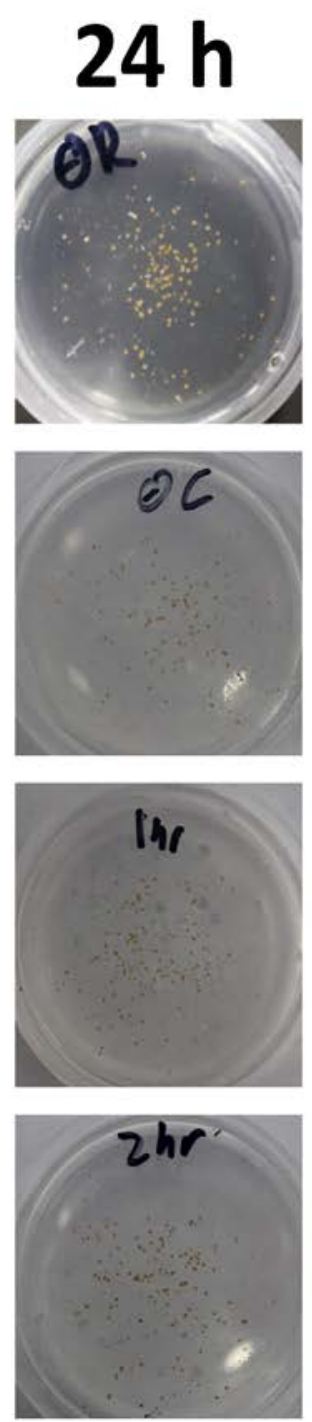

$72 \mathrm{~h}$
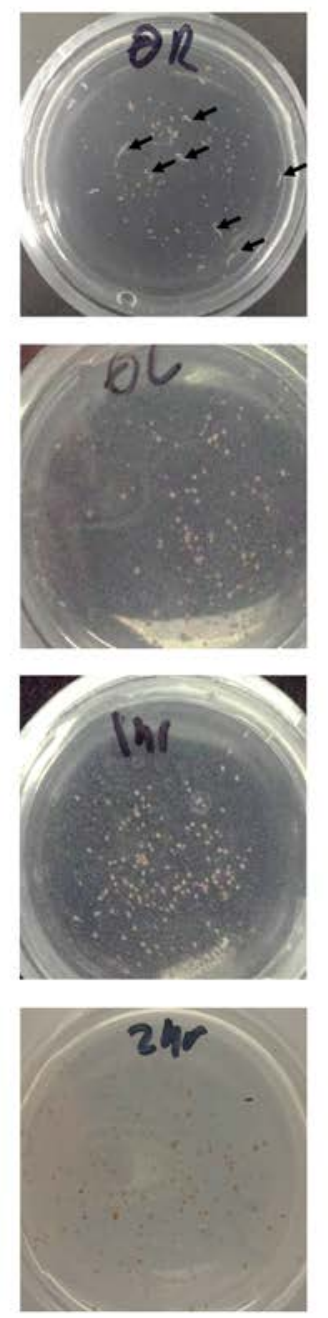

$120 \mathrm{~h}$
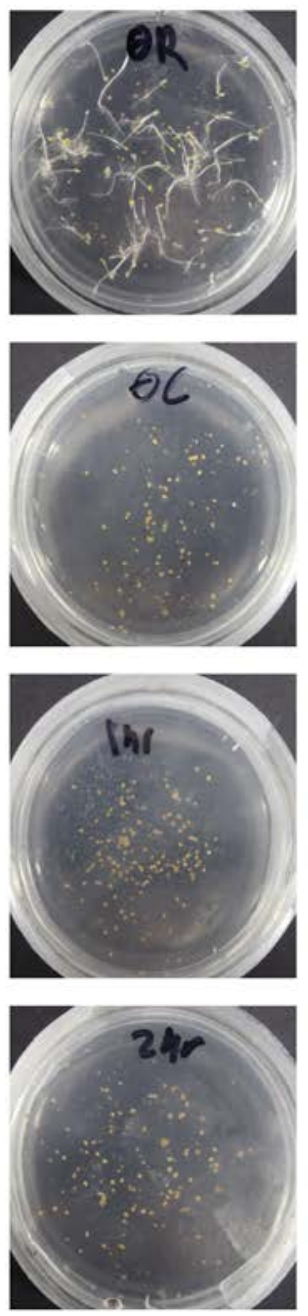

$168 \mathrm{~h}$
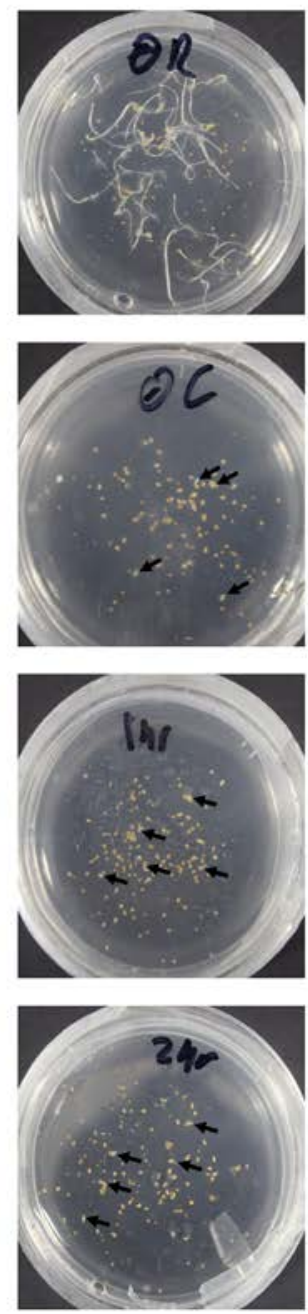

Figure 3. Cold storage of planted seed delays germination for up to $120 \mathrm{~h}$. Approximately 100 seeds were planted on $1 / 2$ MS agar $+1 \%$ sucrose plates. Plates were cold treated for $18 \mathrm{~h}$, followed by $2 \mathrm{~h}$ white light. Plates were then returned to cold, with a subset of plates removed and imaged every $24 \mathrm{~h}$. Representative plates are shown. Arrows indicate seedlings emerging from the seed. 


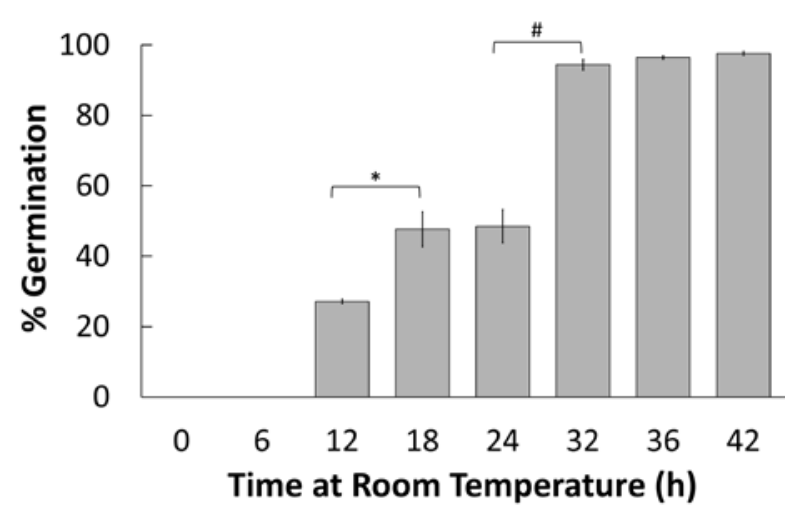

Figure 4. Germination efficiency after return to room temperature. Plates were cold treated for 18 $h$, exposed to 2 h white light, followed by an additional 6 days at $4^{\circ} \mathrm{C}$. After return to room temperature, germination percentage was recorded every $6 \mathrm{~h}$ for 44 h. * $(\mathbf{p}<0.03)$ and \# $(\mathbf{p}<0.01)$ indicate significant result from a Student's T-test. $\mathrm{n}=3$ replicates of approximately 1000 seeds each. Bars represent standard error.

\section{Hours of Growth Maximized Protein Yield}

Uniform germination is induced by shifting the BRICs from cold storage at $4^{\circ} \mathrm{C}$ to ambient temperature aboard the ISS. To determine how long plants should be allowed to grow prior to fixation, a time series was performed analyzing protein yield after three, four, and five days posttransfer to room temperature. Prior to three days, growth was not sufficient to perform extractions. Increasing growth time from three to four days did not appear to significantly impact protein yield (Figure 5). Increasing the time to five days did improve the output. However, due to the high density planting, three days was chosen as the preferred growth time to minimize the impact of crowding stress and ethylene build-up within the PDFUs. Furthermore, we reasoned that most growth after three days could be attributed to vacuole expansion rather than a marked increase in cell division (Gendreau et al., 1997).

\section{RNAlater ${ }^{\circledR}$ Successfully Preserves Protein for Proteomic Analysis}

After three days of growth, samples within the BRICs must be preserved for analysis, potentially months later. Direct transfer to the onboard Minus-Eighty Degree Laboratory Freezer for ISS

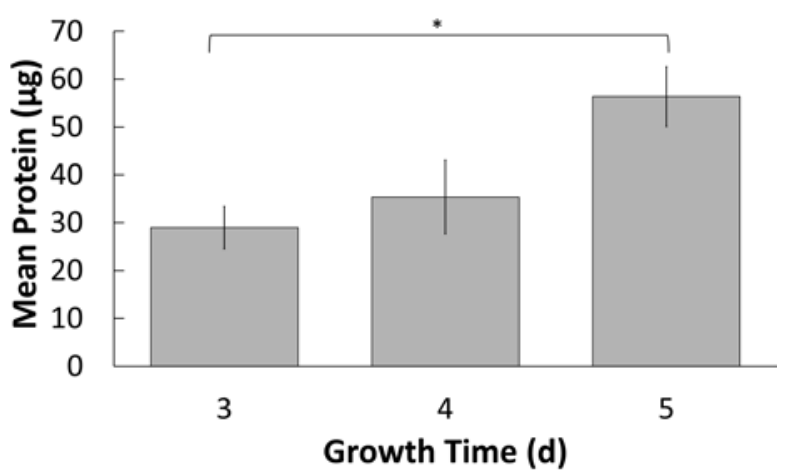

Figure 5. Impact of growth time on mean protein yield. Plates containing $0.016 \mathrm{~g}$ of seed were grown for 1, 2, or $3 \mathrm{~d}$ prior to protein extraction and quantification of total protein. * indicates $\mathbf{p}<0.03$ using a Student's T-test. $n=6$ plates of approximately 1,300 seedlings. Error bars represent SEM.

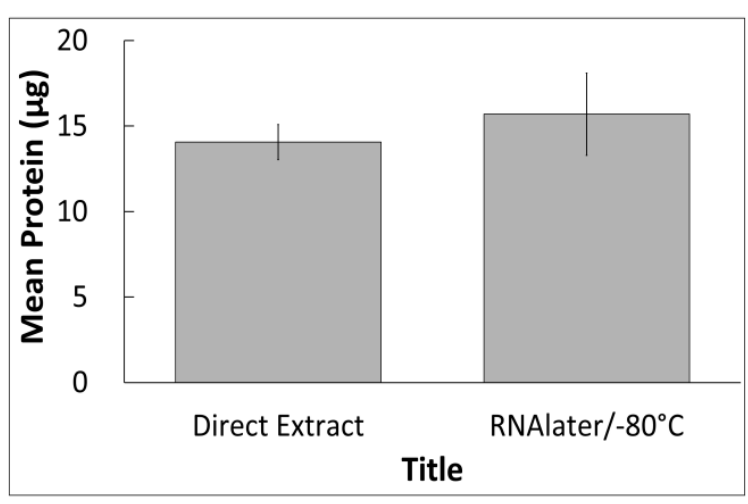

Figure 6. RNAlater ${ }^{\mathrm{TM}}$ stabilizes protein yield. Plates containing $0.016 \mathrm{~g}$ of seed were grown in darkness for $96 \mathrm{~h}$. Seedlings were either soaked in RNAlater $^{\mathrm{TM}}$ for $12 \mathrm{~h}$ prior to freezing at $-80^{\circ} \mathrm{C}$, or subject to immediate protein extraction. Results indicate no signifiant difference in total protein yield between the two approaches. $n=3$ plates of approximately 1300 seedlings. Bars represent SEM.

(MELFI) may not be the best choice because slow freezing may cause changes in the transcriptome or proteome. RNAlater ${ }^{\circledR}$ has been the fixative of choice for previous transcriptomic experiments on the ISS (Beaulieu et al., 2013; Ferl et al., 2011; Kittang et al., 2010; Paul et al., 2005b; Paul and Ferl 2011; Paul et al., 2013), and has been used to preserve protein in Saccharomyces cerevisiae, Arabidopsis callus, and 12 d-old de-etiolated Arabidopsis seedlings (Ferl et al., 2015; Van Eijsden et al., 2013; Zhang et al., 2015). To 
determine if RNAlater ${ }^{\circledR}$ treatment was also able to preserve protein content, plates were flooded with RNAlater ${ }^{\circledR}$ and incubated at $23^{\circ} \mathrm{C}$ for $12 \mathrm{~h}$, frozen at $-80^{\circ} \mathrm{C}$ for $24 \mathrm{~h}$, and thawed prior to protein extraction. Compared to samples extracted immediately after growth, RNAlater $\left(8 /-80^{\circ} \mathrm{C}\right.$ treatment had no significant impact on protein yield (Figure 6). This suggests that the approach prevents major protein degradation during fixation.

\section{DISCUSSION}

Large-scale omics approaches to understanding space biology are appealing because they allow collection of a vast amount of data but are relatively light on space and astronaut-time requirements. For years, microarray, and later RNA-seq, has been used to gather transcriptomic data for plants grown on orbit (Beaulieu et al., 2013; Ferl et al., 2015; Paul et al., 2005a; Paul et al., 2012; Paul et al., 2013; Salmi and Roux, 2008; Salmi et al., 2011a; Salmi et al., 2011b). Unlike physiological data, analyses of these results can continue well beyond the spaceflight, and are often utilized by many researchers to understand specific problems unrelated to the original, but relevant to space biology.

To truly understand the physiological impact of spaceflight, however, gene expression data is insufficient. Protein levels, and often the reversible, post-translational modifications of proteins, are responsible for physiological outcomes on both a cellular and whole-plant level. Therefore, a proteomic approach is more appropriate for determining precisely how plants respond to growth in microgravity. Using proteomics, researchers can isolate specific cellular responses, including protein synthesis, degradation, and activity-altering modifications such as phosphorylation.

\section{High-Density Planting Allows Sufficient Tissue for Proteomic Analysis}

There are technical challenges associated with proteomics experiments aboard the ISS, especially when coupled with BRIC hardware. Proteomics requires much more plant material than transcriptomic approaches. Successful experiments necessitate at least 50-100 g of protein per replicate (Murad et al., 2011). To generate enough tissue within the confines of the PDFUs, we used a dense planting approach, resulting in over 800 seedlings per $60 \mathrm{~mm}$ Petri dish. The primary concern with this approach was the buildup of ethylene altering growth, development, and the proteomic results. To mitigate this possibility, seedlings were allowed to grow only $72 \mathrm{~h}$ after germination induction. This timeline had minimal impact on the overall protein yield, but reduced the time the seedlings spent in crowded conditions. Controls were also run in crowded conditions. Like transcriptomic approaches, proteomics relies on comparison of conditions. Even if ethylene-responsive genes were upregulated in these conditions, the same genes would also be activated in the control samples, negating the impacts. Overall, ethyleneresponsive genes and proteins were not detected in the transcriptomic or proteomic data (data not shown), indicating that they were not activated, or that they were similarly expressed in both samples.

\section{RNAlater ${ }^{\circledR}$ Fixation Protects Protein Content}

Terrestrial experiments normally utilize rapid freezing in liquid nitrogen to preserve protein samples, followed by immediate homogenization or long-term storage at $-80^{\circ} \mathrm{C}$. However, aboard the ISS, liquid nitrogen is not an option. Direct transfer to the $-80^{\circ} \mathrm{C}$ freezer is not desirable because slow freezing could induce gene and protein expression in response to temperature change and ice crystal induced cell lysis. Traditional fixatives, such as glutaraldehyde, pose health hazards and are not allowed on board the ISS.

The preservative RNAlater ${ }^{\circledR}$ has long been used as a fixative appropriate for on-orbit transcriptomic experiments, as it works well to preserve nucleic acids (Drakulovski et al., 2013; Saito et al., 2011). Other recent work has shown RNAlater ${ }^{\circledR}$ to also preserve protein in a wide variety of biological samples (Abbaraju et al., 2011; Gorokhova et al., 2005; Saito et al., 2011). RNAlater ${ }^{\circledR}$ contains high levels of quaternary ammonium sulfates and cesium sulfates, leading to protein denaturation within samples (Bennike et al., 2016). This activity prevents sample degradation by DNase, RNase, and protease, as well as the activity of protein modifying enzymes. Results here indicate that overall the quantity and 


\section{Hutchinson et al. -- Arabidopsis Proteomic Analysis}

quality of protein are consistent between RNAlater ${ }^{\circledR}$-treated and flash-frozen samples. However, this work does not address the efficacy of RNAlater ${ }^{\circledR}$ to limit changes to the proteome.

\section{CONCLUSION}

The approach outlined here has been executed successfully to obtain sufficient protein from BRIC samples on the ISS. Based on these results, we recommend allocating three PDFUs per replicate. Through managing seed number and growth time, these methods allow proteomic analysis of Arabidopsis tissue using this specific hardware. Furthermore, manipulation of germination through temperature change, as well as RNAlater ${ }^{\circledR}$ fixation, drastically limit crew time, making this an attractive approach for future proteomic analysis of Arabidopsis mutants requiring only short, etiolated growth.

\section{ACKNOWLEDGEMENTS}

This work was supported by NASA (\#NNX13AM48G to SEW and DRL) with supplemental funding provided by NASA GeneLab. The authors would also like to thank Simon Gilroy for suggesting transfer to room temperature as a method for germination of BRIC-grown seedlings, and Marilyn Hayden for help collecting data.

\section{REFERENCES}

Abbaraju NV, Cai Y, Rees BB (2011) Protein recovery and identification from the gulf killifish, Fundulus grandis: comparing snapfrozen and RNAlater ${ }^{\circledR}$-preserved tissues. Proteomics 11: 4257-4261

Basu P, Luesse DR, Wyatt SE (2015) Proteomic approaches and their application to plant gravitropism. Plant Gravitropism: Methods and Protocols 1309: 119-132

Beaulieu J, Giguère I, Deslauriers M, Boyle B, MacKay J (2013) Differential gene expression patterns in white spruce newly formed tissue on board the International Space Station (ISS). Advances in Space Research 52: 760-772

Bennike TB, Kastaniegaard K, Padurariu S, Gaihede M, Birkelund S, Andersen V, Stensballe A (2016) Comparing the proteome of snap-frozen, RNAlaterpreserved, and formalin-fixed paraffinembedded human tissue samples. European Proteomics Association (EuPA) Open Proteomics 10: 9-18

Crabbé A, Schurr MJ, Monsieurs P, Morici L, Schurr J, Wilson JW, Ott CM, Tsaprailis G, Pierson DL, Stefanyshyn-Piper H, Nickerson CA (2011) Transcriptional and proteomic responses of Pseudomonas aeruginosa PAO1 to spaceflight conditions involve Hfq regulation and reveal a role for oxygen. Applied and Environmental Microbiology 77: 1221-1230

Drakulovski P, Locatelli S, Butel C, Pion S, Krasteva D, Mougdi-Pole E, Delaporte E, Peeters M, Mallié M (2013) Use of RNAlater $^{\mathrm{TM}}$ as a preservation method for parasitic coprology studies in wild-living chimpanzees. Experimental Parasitology 135: 257-261

Ferl RJ, Koh J, Denison F, Paul A-L (2015) Spaceflight induces specific alterations in the proteomes of Arabidopsis. Astrobiology 15: 32-56

Ferl RJ, Zupanska A, Spinale A, Reed D, Manning-Roach S, Guerra G, Cox DR, Paul A-L (2011) The performance of KSC fixation tubes with RNALater for orbital experiments: a case study in ISS operations for molecular biology. Advances in Space Research 48: 199-206

Gendreau E, Traas J, Desnos T, Grandjean O, Caboche M, Hofte H (1997) Cellular basis of hypocotyl growth in Arabidopsis thaliana. Plant Physiology 114: 295-305

Gorokhova E (2005) Effects of preservation and storage of microcrustaceans in RNAlater on RNA and DNA degradation. Limnology and Oceanography: Methods 3: 143-148

Griffin TJ, Gygi SP, Ideker T, Rist B, Eng J, Hood L, Aebersold R (2002) Complementary profiling of gene expression at the transcriptome and proteome levels in Saccharomyces cerevisiae. Molecular and Cellular Proteomics 1: 323-333

Grimm D, Wise P, Lebert M, Richter P, Baatout S (2011) How and why does the proteome respond to microgravity? Expert Review of Proteomics 8: 13-27 


\section{Hutchinson et al. -- Arabidopsis Proteomic Analysis}

Kittang A, Kvaløy B, Winge P, Iversen T-H (2010) Ground testing of Arabidopsis preservation protocol for the microarray analysis to be used in the ISS EMCS Multigen-2 experiment. Advances in Space Research 46: 1249-1256

Kuznetsov O, Brown CS, Levine HG, Piastuch WC, Sanwo-Lewandowski MM, Hasenstein $\mathrm{KH}$ (2001) Composition and physical properties of starch in microgravity-grown plants. Advances in Space Research 28: 651658

Ma Y, Cheng Z, Wang W, Sun Y (2007) Proteomic analysis of high-yield rice variety mutated from spaceflight. Advances in Space Research 40: 535-539

Millar KD, Johnson CM, Edelmann RE, Kiss JZ (2011) An endogenous growth pattern of roots is revealed in seedlings grown in microgravity. Astrobiology 11: 787-797

Murad AM, Souza GHMF, Garcia JS, Rech EL (2011) Detection and expression analysis of recombinant proteins in plant-derived complex mixtures using nanoUPLC-MS ${ }^{\mathrm{E}}$. Journal of Separation Science 34: 26182630

Paul A-L, Ferl RJ (2011) Using Green Fluorescent Protein (GFP) reporter genes in RNAlater ${ }^{\mathrm{TM}}$ fixed tissue. Gravitational and Space Biology 25: 40-43

Paul A-L, Levine HG, McLamb W, Norwood KL, Reed D, Stutte GW, Wells HW, Ferl RJ (2005b) Plant molecular biology in the space station era: utilization of KSC fixation tubes with RNAlater ${ }^{\mathrm{TM}}$. Acta Astronautica 56: 623-628

Paul A-L, Popp MP, Gurley WB, Guy C, Norwood KL, Ferl RJ (2005a) Arabidopsis gene expression patterns are altered during spaceflight. Advances in Space Research 36: 1175-1181

Paul A-L, Zupanska AK, Ostrow DT, Zhang Y, Sun Y, Li JL, Shanker S, Farmerie WG, Amalfitano CE, Ferl RJ (2012) Spaceflight transcriptomes: unique responses to a novel environment. Astrobiology 12: 40-56

Paul A-L, Zupanska AK, Schultz ER, Ferl RJ (2013) Organ-specific remodeling of the Arabidopsis transcriptome in response to spaceflight. BioMed Central (BMC) Plant Biology 13: 112

Saito MA, Bulygin VV, Moran DM, Taylor C, Scholin C (2011) Examination of microbial proteome preservation techniques applicable to autonomous environmental sample collection. Frontiers in Microbiology 2: 215

Salmi ML, Bushart TJ, Roux SJ (2011a) Autonomous gravity perception and responses of single plant cells. Gravitational and Space Biology 25: 6-13

Salmi ML, Roux SJ (2008) Gene expression changes induced by spaceflight in singlecells of the fern Ceratopteris richardii. Planta 229: 151-159

Salmi ML, ul Haque A, Bushart TJ, Stout SC, Roux SJ, Porterfield DM (2011b) Changes in gravity rapidly alter the magnitude and direction of a cellular calcium current. Planta 233: $911-920$

Van Eijsden RG, Stassen C, Daenen L, Van Mulders SE, Bapat PM, Siewers V, Goossens KV, Nielsen J, Delvaux FR, Van Hummelen P (2013) A universal fixation method based on quaternary ammonium salts (RNAlater ${ }^{\mathrm{TM}}$ ) for omics-technologies: Saccharomyces cerevisiae as a case study. Biotechnology Letters 35: 891-900

Vanderschuren H, Lentz E, Zainuddin I, Gruissem W (2013) Proteomics of model and crop plant species: status, current limitations, and strategic advances for crop improvement. Journal of Proteomics 93: 5-19

Zhang Y, Wang L, Xie J, Zheng H (2015) Differential protein expression profiling of Arabidopsis thaliana callus under microgravity on board the Chinese SZ-8 spacecraft. Planta 241: 475-488 